\title{
RELATIONSHIP BETWEEN TEACHERS' PERCEPTIONS OF PRINCIPALS' ENHANCEMENT OF ICT IN TEACHING AND LEARNING STRATEGY AND STUDENTS' ACADEMIC PERFORMANCE IN PUBLIC SECONDARY SCHOOLS IN NAIROBI CITY COUNTY, KENYA
}

\author{
Consolata Muthoni Kimuya ${ }^{1 i}$, \\ Gerald Kimani², \\ James Mwaura ${ }^{1}$ \\ ${ }^{1}$ School of Education, \\ Maasai Mara University, \\ Kenya \\ ${ }^{2}$ School of Education, \\ University of Nairobi, \\ Kenya
}

\begin{abstract}
:
In a rapidly changing era, teachers' perceptions of the principals' management of school wide change strategies are crucial. ICT in increasingly being viewed as providing teaching and learning that increases learners' creative and intellectual resources especially in today's information society. The success is however dependent on the way principals manage the process of school wide-change. The purpose of this study was to examine the relationship between Teachers' Perceptions of Principals' Enhancement of ICT in Teaching and Learning Strategy and Students' Academic Performance in Public Secondary Schools in Nairobi City County. The study fitted within cross-sectional descriptive survey designs with a target population comprising 94 public secondary schools, 94 principals, and 906 teachers. The schools were stratified to categories; national, extra-county, and county schools to ensure equal representation during sampling. Stratified simple random sampling methods were used to select schools, principals and teachers. The sample size comprised 30 principals and 304 teachers. Data was collected using teachers' questionnaire and a school data form. Data were analysed through descriptive and inferential statistics. The hypothesis was tested at .05 alpha levels using linear regression analysis. It was found that there was a statistically significant association between teachers' perceptions of principals' enhancement of ICT in teaching and learning strategy and students' academic performance $(p<.001)$. It was concluded that principals' enhancement of ICT in teaching and learning was perceived as a factor influencing students' academic performance. The study brings to light that
\end{abstract}

${ }^{i}$ Correspondence: email mkimuya@yahoo.co.uk 
information and communication technology positively affects students' academic achievement and retention and ICT was found more compelling, effective and valuable in teaching when contrasted with other techniques of teaching.

Keywords: teachers' perceptions, enhancement of ICT, academic performance, public secondary schools

\section{Introduction}

Globally, educational management in the 21st Century is expected to focus on the achievement of the Sustainable Development Goals (SDGs) which were identified by 193 countries that came together in 2015, Kenya being one of them (UNDP, 2015). The report explains that these countries agreed on the year 2030 Agenda on Sustainable Development Goals which each of these countries committed themselves to fight poverty and attain sustainable development within 15 years. Two of the modular building-blocks of SDGs achievement goals ware education, gender, inequality and digital revolution for sustainable development (Sachs, Traub, Mazzucato, Messner, Nakicenovic, \& Rockström, 2019). A study by Beare, Caldwell, and Millikan (2005), argue that complex and dynamic changes are required for sustained school improvement in the 21st Century. West, Jackson, Harris, \& Hopkins (2000), ascertain that changes in economic conditions, technological developments, market changes, legal amendments, and changing customer preferences due to social and political changes are considered among the external reasons of organizational change. Oztop (2014) found that human resources' problems, organizational inadequacies, financial problems, managerial behaviors and decisions as well as in-house innovation are considered among the internal reasons for organizational change.

The new millennium in the 21st century is indicated by rapid change and a complex society. Beare, Caldwell, \& Millikan (2005), argue that complex and dynamic changes are required for sustained school improvement (West, Jackson, Harris, \& Hopkins, 2000). This shift requires numerous changes in educational context. Hrebiniak (2013), identifies eleven changes of educational reform, which is a part of the strategies of the school-wide change in that they involve the judgment of institutional success on the quality of student learning, shared responsibility in student learning and providing access to educational services for learners. Hrebiniak continued to purport that constant identification, development, testing, implementation, and assessment of a variety of effective learning technologies including new applications of computer and information technology which are great changes likened to school-wide change and it is expected to initiate students' achievement leading to improved academic performance. A school whose main responsibility is the design of teaching-learning methods emphasis on the traditional responsibility of instruction, particularly in the form of teaching, teams of specialists from cross-disciplinary or non-disciplinary working collaboratively to 
develop programs to increase student competency will greatly improve in students' outcome ( Hrebiniak, 2013).

In Africa region, education restructuring is evident. Most countries are struggling to implement the required school-wide change and innovation in education sector. Principals need to embrace the school-wide change which involves a wide range of vital changes in which school principals as agents of change utilize to facilitate school improvement through educational innovations (Madsen, 2015). Principals need to plan for better school infrastructure in their school-wide change strategies in order to influence students' academic performance. In South Africa, the continuous poor performance of the learners is due to lack of facilities, learning materials as well as resources which is detrimental to the developing country as $37 \%$ of the population is made up of the youth (Berg, Taylor, Spaull \& Armstrong, 2011). The study ascertains that recent implementation of system-wide change strategy in South Africa is meant to build management capacity that would drive education change directed at improving teaching and learning in the school districts. This implies that the education system needs to apply the school-wide change strategies. Berg et all (2011) ascertains that South Africa's poor performance, as measured in local and international tests, is driven primarily by the language disadvantage. With respect to indirect influences in education in South Africa, it is argued that language transcends both direct and indirect influences (Mji, 2006). Mji recommended that second language speakers of the language of instruction generally need tuition in that language which is English.

Kenya, like other countries, is in the race of attaining Sustainable Development Goals (SDGs) alongside the Vision 2030 which envisions that Kenya will be an industrialized nation by year 2030 (Society for International Development, 2010). For the country to attain these goals, education requires management that is clearly established for all stakeholders (Vision 2030 delivery secretariat, 2015). The development of education and training is part of the road map towards the actualization of the social transformation hinged onto the social pillar of Kenya Vision 2030 (Kaimenyi, 2015). Management of secondary schools, therefore, is an important aspect towards attainment of the set national and international obligations.

The teachers 'positive perception of the principals' management of school wide change strategies are crucial. Swanepoel (2008), in his study on the school reform found that school-based management has recently emerged as the instrument to accomplish the decentralization of decision-making powers to school level. He asserts that the success thereof depends largely on school principals' disposition regarding teacher involvement. Okiiya (2015), on change management and performance of public secondary schools in Siaya County found that change in teaching styles significantly influence academic performance. The literature reviewed in this study did not discuss the $21^{\text {st }}$ century schoolwide change management strategies which may influence improvement students' academic performance more significantly. This study sought to address this gap which is summed up as principals' management of school wide-change strategies and which may 
be required as a comprehensive range of change to better students' academic performance in the 21st century education strategy.

\section{Research Objective}

To establish the relationship between teachers' perceptions of principals' enhancement of ICT in teaching and learning strategy and students' academic performance in public secondary schools

\section{Research Hypothesis}

There is no significant relationship between teachers' perceptions towards principals' enhancement of ICT in e-learning and students' academic performance at public secondary schools

\section{Literature Review}

\subsection{Teachers' Perceptions of Principals' Enhancement of ICT in Teaching and Learning on Students' Academic Performance}

Information and Communication Technology (ICT) is defined as a diverse set of technological tools and resources used to communicate, and to create, disseminate, store, and manage information (Victoria \& Chikwature, 2016). The author also argues that the use of ICT to achieve education and development goals is the great skill of the 21st Century. The study reveals that a well-designed technological solution can be used to disseminate resources, connect students to information, enhance teachers' practices and students' performance in all subject areas, improve school management and support data-driven policymaking. A study by Ghavifekr and Wan Rosdy (2015), purport that ICT will assist teachers to embrace the global requirements by replacing traditional teaching methods with a technology-based teaching and learning. Ghavifekr and Wan Rosdy in their study on analyzing teachers' perceptions on effectiveness of ICT integration to support teaching and learning process in the classroom in Malaysia found that ICT integration has a great effectiveness for both teachers and the students. Further, the study found that teachers' well-equipped preparation with ICT tools and facilities improved students' achievements especially in academic excellence.

Kennah (2016), sees ICT as the combination of technologies for collecting, storing, processing, communicating and delivering information. The author continues to purport that ICT has become an important source of innovation and improvement of efficiency for many sectors across the globe. The study confirms that ICT provides productive teaching and learning by increasing learners' creative and intellectual resources especially in today's information society. Escalente (2005), has it that technology travels with people. The author asserts that ICT is regarded as an engine for growth and tool for 
empowerment with profound implications for education, change and socio-economic development. ICT tools such as videos, televisions, multimedia and computer software which combines text, sound, and colorful moving images can be used to provide challenging and authentic content that will engage the students in the learning process (Ikwuka \& Eluemunor, 2017).

ICT has brought a tremendous change in society by connecting the whole world. It has produced and enhanced change in teaching and learning all over the world. UNESCO (2011), described ICT as a tool that can complement, enrich and transform education for the learners. The UNESCO report further noted that ICT innovation has provided access to the whole world through collaboration with education providers. The report further ascertains that the teaching and learning materials can be shared online with teachers and students and therefore making teaching and learning more motivating and enjoyable. The UNESCO report ascertains that the education sector, particularly the application of ICT has become so critical that it is part of the learning process for university students both outside and inside the classroom setting. The government and other stakeholders in the education sector such as university management and researchers have invested millions of dollars to adopt ICT in the education system during the last two decades (Jonassen, 2000). Most universities have fully adopted ICT and have recorded immense advancement in the application of ICT for the improvement of teaching and learning methods, research, and have created positive perception of teachers on the change in the teaching and learning process. It is, however, not clear what impact the ICT applications have on the students' academic performance and other achievements. Positive perception of teachers on principals' management of school-wide change strategies of ICT enhancement in teaching and learning may improve the students' academic achievement hence the need for this study.

USAID education policy implemented in the MOE (2016), is among the world's largest bilateral supporters of ICT projects in education. The policy use technology to increase access to basic education, to support the development of literacy and numeracy skills, to improve the management of schools and education systems, to enhance the relevance and quality of learning and to extend educational opportunities to marginalized and vulnerable populations, including those in crisis and conflict. In South Africa, despite the massive investment in the integration of ICT in many secondary schools, the practical use of the ICT tools by teachers remain in a preliminary stage with little significance in the educational outcome (Guma Ali, 2013). "One laptop per child" initiative have not yielded significant results especially in less developed countries (Ames, 2010). A study by Suhr, Hernandez, Grimes, and Warschauer, (2010), in Birmingham, USA to investigate whether a one-to-one laptop program could help improve English language arts (ELA) test scores of upper elementary students, found that students enjoyed using multimedia, searching the internet, and writing their papers on computer. The study also found that students wrote longer papers than was typical in non-laptop classes, and that the laptop students were able to revise their work better. The 
study by Suhr et al explored the performance results by comparing changes in the ELA test scores of the group of students who entered a one-to-one laptop program in the fourth-grade to a similar group of students in a traditional program in the same school district. The study revealed that the laptop students outperformed non-laptop students in their performance of ELA total score.

The United Nations Educational, Scientific and Cultural Organization (UNESCO) created and used the "One Laptop Per Child" (OLPC) initiative as a means of closing the digital divide gap between developed and developing nations on the use of ICT (MOE, 2016). Research has shown that the absence of efficient and right ICT development policies in most African countries including Cameroon has widened the information gap between the developed and the less developed countries (UNDP, 2015). The rationale of studying academic performance in the context of ICT adoption is to present a significant relationship that exists between the two variables. Research has shown that the use of ICT in education can increase students' motivation, deepen their understanding, promote active collaborative and lifelong learning (Jonassen, 2000). Another study by Guma Ali (2013) ascertains that ICT has created a virtual interaction platform where teachers, parents and students can communicate easily through e-mail, chatting, Skype, teleconferencing, videoconferencing, Ali ascertains that ICT has also led to a 24 hours easy and quick access to various learning resources globally which helps in saving time for both teachers and students. ICT is therefore changing the nature of teaching and learning. In the last decade, many studies have been undertaken on ICT implementation in education and reformation of instruction technology (Gikundi, 2016). A study by Imon (2017), on ICT integration in secondary education in Bangladesh found that the extent of ICT usage in the classroom was minimal due to the challenges of availability of the ICT infrastructure.

Laaria (2013) conducted a study on the impact of ICTs on students' academic performance. The study found that a distinctive though negative effect of ICT on performance was revealed which questions the effectiveness of educational policies in Tunisia. Hussain and Suleman (2017), also conducted a study on effects of ICT on students' academic achievement and retention in Chemistry subject at Secondary Level in Karak District, Khyber Pakhtunkhwa Pakistan. The findings indicated that there was significant variance in academic achievement of control and experimental groups. It therefore revealed that information and communication technology positively affects students' academic achievement and therefore the use of ICT in teaching and learning was found to be more compelling, effective and valuable in teaching of chemistry when contrasted with conventional techniques of teaching. The study recommended that information and communication technology should be used in teaching chemistry for enhancing students' academic achievement at secondary level. The study also recommended that other subjects should also apply this method of teaching with ICT technology. A study by Mbaeze, Ukwandu and Anudu (2010), carried out to investigate the influence of ICT on students' achievement found that there was statistically 
significant relationship between ICT on students' academic performance. Basri and Alandejani (2018), in their study which investigated and explored the adoption of information communication technology by the universities and the impact it makes on the university students' academic performance in Saudi universities found that there exists a relationship between ICT adoption and academic performance in a conservative environment. The study also found that ICT adoption resulted in the improvement of the performance of female students more than the male. However, students' who majored in ICT were found to be making no impact on students' academic achievement.

Ikwuka and Adigwe (2017), study examined the effect of Information Communication Technology on secondary school students' academic performance in Christian Religious Studies (CRS) in Oshimili North Local Government Area of a Delta State. The results showed that students who were taught with ICT had better academic performance on CRS and that the gender had no significant effect in the academic performance of students who were taught CRS with ICT instructional package. Based on the findings, it was recommended that Christian Religious Studies' teachers should use ICT for teaching CRS in secondary schools. Another study by Mohammad et. al (2019), examined the effect of ICT on the students' academic performance at different private universities in Chittagong, Bangladesh. Results indicated that there was a significant relationship between ICT use and students' academic performance. Also, student's addiction to ICT was seen to have a significant influence on the comparative measurement in identifying the academic performance of the students. Khan, Khan, Din and Muhammad (2015) also did a study on impact of Information and Communication Technology (ICT) on the students and his/her information to access in the Gomal University, Dera Ismail Khan Pakistan. The objectives were to explore the ways how students access to information, highlights that acceptability of ICT among schedule for getting information; establish what percent of schedule use ICT for gaining information and lastly to explore the problem faced by students in getting information. The study revealed that many students considered ICT tools very helpful in that it helped them to do assignments and also ICT enabled students with special needs or difficulties to do their work easily. The study revealed that ICT helped to reduce the social disparities between students, since they collaborate in teams in order to achieve a given task. Students also assumed responsibilities when they used ICT to organize their work through digital portfolios or projects. In addition, the study showed that ICT had significant impact on students' teaching and learning processes.

In Kenya, a study by Oyeila (2016), on integrating ICT in Mathematics education at secondary level in Nairobi City County found that teachers were not well prepared and that schools were not well equipped with ICT infrastructure. Mbugua (2016), in his study on Integration of ICT in teaching in public secondary schools in Nakuru County, Kenya found that ICT facilities in the sampled schools were inadequate and that teachers had only basic or no ICT skills. Further, Mbugua found that financial constraints and lack of ICT resources ware some of the challenges teachers faced in integration of ICT in 
teaching and learning. Mbugua also purport that there is a positive significant relationship between integration of ICT and students' academic performance at 0.05 alpha significance levels. The study concluded that integration of ICT is quite important at the current dispensation in teaching and learning. Mbugua also recommended that more studies be done in more areas. A study by (Abbas \& Asghar, 2010), on the analysis of literature reviewed and the results of real-life cases of organizations shows, that management with the competencies of "Vision" and "Innovative Approach" along with other characteristics can prove more effective to conclude the complex phenomena of organizational change with success. Further, Abbas and Asghar ascertains that the successful organizational change can leads to innovation for an organization, which is the key for the long-term success and sustainability. They assert that the ICT technology should be embraced by the managers as the new tool for innovation in the great change for teaching and learning to attain better students' achievement. An investigation by Laaria (2013), on Leadership Challenges in the Implementation of ICT in Public Secondary Schools in Kenya found that school principal determines how Information Communication Technology (ICT) is implemented and its subsequent impact on teaching and learning. Laaria concludes that this process involves the Principal as a school manager to lead and manage the implementation. A positive attitude of school principal towards the implementation of ICT will encourage the teachers and the students embrace the implementation which may improve the students' achievement.

These studies however did not compare the students' performance with ICT integration. Further, they did not investigate on innovation and improvisation by teachers by Smart Phones already available in the market and therefore the need for this study. Numerous studies have been undertaken to investigate the relationship between ICT and students' academic performance; however, these studies have not been able to establish precisely the impact of ICT on students' performance. These studies have posed two core challenges: first, it is difficult to determine the performance of students since the common approach used by many researchers accredits the curriculum responsible for the performance achievement in terms of grade (Alandejani \& Almadani, 2018). However, Ali, Zhou, Hussain, and Nair (2016), as well as Rose and Kadveka (2015), criticize these studies, blaming them of adopting a narrow approach, and suggest an alternative approach to consider the influence of ICT on students' attitude, competency, and skills in addition to curriculum. The study found that ICT facilities were inadequate, and teachers had only basic or no ICT skills (Mbugua, 2016).

\section{Research Methodology}

A descriptive cross sectional survey design was adopted targeting 94 public secondary schools, 94 principals, and 906 teachers. The schools were stratified to categories; national, extra-county, and county schools to ensure equal representation during sampling. Stratified simple random sampling methods were used to select schools, 
principals and teachers. The sample size comprised 30 principals and 304 teachers. Data was collected using teachers' questionnaire and a school data form. Data was collected using structured questionnaires for teachers and principals \& instruments validated \& adjustments done after the pilot study. Reliability was determined using Cronbach's Alpha coefficient that yielded 0.753 and 0.873 respectively. Data was analysed through descriptive and inferential statistics. The study hypothesis was tested at .05 alpha levels using linear regression analysis.

\section{Results and Discussion}

\subsection{Teachers' Perception of Principals' Enhancement of ICT in Teaching and Learning and Students' Academic Performance}

A report by UNESCO (2018), reported that Information and Communications Technology (ICT) has brought a tremendous change in education and society. It has connected the whole world. ICT has produced and enhanced change in teaching and learning all over the world. To establish the relationship between the teachers' perception of their principals' enhancement of ICT in teaching and learning and students' academic performance in public secondary schools in Nairobi City County, the teachers were asked to indicate their views on their principals' enhancement of ICT in teaching and learning in schools and whether it improved teaching and learning.

In the analysis of the Likert scale questions, the researcher converted the Likert scale in to means where a mean of $1-1.4$ was within the range of strongly disagree, 1.5 2.4 was within a range of disagree, 2.5 - 3.4 was within the range for the undecided, $3.5-$ 4.4 representing a range of agree while 4.5 to 5.0 was within a range of strongly agree. The scales were later collapsed into two levels and interpreted as; 1.0 - 2.4 (negative perceptions $=1$ ); and $2.5-5.0$ (positive perceptions $=2$ ). Table 1 shows the results.

Table 1: Teachers' perception of their Principals' enhancement of ICT

in teaching and learning in schools and its effect on students' teaching and learning

\begin{tabular}{|c|c|c|c|}
\hline Statement & $\mathbf{N}$ & $M$ & $S D$ \\
\hline $\begin{array}{l}\text { The principal supports the use of information and communications technology (ICT) } \\
\text { in classroom teaching (e-learning) which has helped to improve students' academic } \\
\text { performance }\end{array}$ & 290 & 4.05 & 0.96 \\
\hline $\begin{array}{l}\text { The principal has facilitated the ICT equipment (computers and projectors) which } \\
\text { are strategically placed for e-learning environment which has helped to improved } \\
\text { students' academic performance }\end{array}$ & 290 & 3.91 & 1.05 \\
\hline $\begin{array}{l}\text { The principal emphasizes the use of ICT in classroom teaching through the use of an } \\
\text { e-learning time table which has helped to improve students' academic performance }\end{array}$ & 290 & 3.73 & 1.08 \\
\hline $\begin{array}{l}\text { The principal has provided the ICT programme for processing students' } \\
\text { examinations for faster exam feedback which brings about improvement of } \\
\text { students' academic performance }\end{array}$ & 290 & 3.25 & 0.94 \\
\hline $\begin{array}{l}\text { The principal has forged partnership with parents and organizations to address the } \\
\text { ICT resources and training of teachers which has helped to improve the students' } \\
\text { academic performance }\end{array}$ & 290 & 3.25 & 1.17 \\
\hline
\end{tabular}




\begin{tabular}{|l|c|c|c|}
\hline \hline $\begin{array}{l}\text { The principal motivates the teachers to use ICT in preparing remedial e-materials } \\
\text { for quick revision and understanding which improves the students' academic } \\
\text { performance }\end{array}$ & 290 & 3.75 & 1.01 \\
\hline $\begin{array}{l}\text { The principal has equipped the school with enough computers, projectors and e- } \\
\text { learning materials for teachers and students which hinders students' improvemen5t } \\
\text { of academic performance }\end{array}$ & 290 & 2.30 & 1.24 \\
\hline $\begin{array}{l}\text { The principal has not provided the teachers with internet access for preparation and } \\
\text { updating of e-learning materials which hinders improvement of students' academic } \\
\text { performance }\end{array}$ & 290 & 2.19 & 1.25 \\
\hline $\begin{array}{l}\text { The principal encourages teachers to buy their own laptops which are maintained } \\
\text { by the school hence motivating teachers to utilize better teaching materials which } \\
\text { has helped improve students' academic performance }\end{array}$ & 290 & 2.73 & 1.16 \\
\hline $\begin{array}{l}\text { The principal is computer literate and uses e-learning programmes in his/her class } \\
\text { teaching which serves as a role model for teachers and which contributes to } \\
\text { students' improved academic performance. }\end{array}$ & 290 & 3.43 & 1.12 \\
\hline Overall mean & 290 & 3.25 & 0.90 \\
\hline
\end{tabular}

Findings in table 1 revealed that teachers agreed that the principals: support use of ICT in classroom teaching which has helped to improve students' academic performance (M $=4.05$; $\mathrm{SD}=0.96)$; facilitated the ICT equipment which are strategically placed for elearning environment which has helped to improved students' academic performance $(\mathrm{M}=3.91$; $\mathrm{SD}=1.05)$; and they motivate teachers to use ICT in preparing remedial ematerials for quick revision and understanding which improves the students' academic performance $(\mathrm{M}=3.75 ; \mathrm{SD}=1.01)$. The different means and standard deviations could be indicators of challenges faced by the newly established schools where teaching and learning equipment in ICT could be minimal hence teachers giving a low score.

Data further indicate that teachers agreed that principals had forged partnership with parents and organizations to address the ICT resources and training of teachers which has helped to improve the students' academic performance $(M=3.25 ; \mathrm{SD}=1.17)$. These findings agreed with the report on the Sessional Paper (No 1 of 2012) which reported that principals and teachers would be trained in order to embrace the new change in educational provision. The teachers were also in agreement that principals encouraged teachers to buy their own laptops which were maintained by the school hence motivating teachers to utilize better teaching materials which help in improving students' academic performance $(\mathrm{M}=2.73$; $\mathrm{SD}=1.16)$. The mean was however low which may be due to constraints of funds on the teachers' and school administration. The overall mean $(\mathrm{M}=3.25, \mathrm{SD}=.90)$ was interpreted as positive perceptions. A linear regression analysis with performance data from 2015, 2016, 2017 and 2018 was run with principals' enhancement of ICT in teaching and learning strategy variable to test the hypothesis. 


\subsection{Test of hypothesis}

H01: There is no significant relationship between the teachers' perceptions towards principals' enhancement of ICT in e-learning strategy and students' academic performance in public secondary schools in Nairobi City County.

To determine the relationship, a linear regression analysis was conducted with the composite school KCSE mean score and mean of teachers' perceptions of principals' enhancement of ICT in e-learning strategy and students' academic performance. The results are presented on table 2, 3, and 4. First, a model fit summary is discussed:

Table 2: Overall model fit 3

\begin{tabular}{|l|c|}
\hline Number of observations & 874 \\
\hline F & 4.13 \\
\hline Prob. > F & 0.000 \\
\hline R - squared & 0.1283 \\
\hline Adjusted R - squared & 0.0972 \\
\hline Root SME & .908012 \\
\hline
\end{tabular}

From the model summary, it was found that enhancement of ICT in e-learning strategic planning guidelines explained a moderate amount of the variance in the value of student academic performance at $\operatorname{KCSE}\left(\mathrm{F}(1,874)=3.6, \mathrm{p}<.001, \mathrm{R}^{2}=.063, \mathrm{R}^{2}\right.$ Adjusted = .042). The $\mathrm{R}^{2}=0.13$ indicates that $13 \%$ of the variance in KCSE scores can be predicted from the enhancement of ICT in e-learning strategy.

Table 3: ANOVA 3

\begin{tabular}{|l|c|c|c|c|c|}
\hline Source & SS & df & MS & F & Prob. $>$ F \\
\hline Model & 102.2712 & 30 & 3.409041 & 4.13 & 0.000 \\
\hline ICT in e-learning & 102.2712 & 30 & 3.409041 & 4.13 & 0.000 \\
\hline Residual & 695.0423 & 843 & 0.824487 & & \\
\hline Total & 797.3135 & 873 & 0.913303 & & \\
\hline
\end{tabular}

The sum of squares (SS) for the model is 102.27 with 30 degrees of freedom (df). This line results in a mean square (MS) of 3.40. The corresponding F statistic is 4.13 and has a significance level of 0.001 . These results indicated that the model was a significant predictor of KCSE performance, $\mathrm{F}(30,843)=4.13, \mathrm{p}=.001$. The significance value, $\mathrm{p}=$ 0.0001 is less than $p=0.05$, the regression model significantly predicts KCSE score. Therefore, the null hypothesis was rejected. There is a statistically significant relationship between teachers' perceptions of principals' enhancement of ICT in e-learning strategy and students' academic performance. 
Table 4: Regression analysis of KCSE performance data with enhancement of ICT in teaching and learning strategy

\begin{tabular}{|l|c|c|c|c|c|c|}
\hline Mean_score & Coef. & Std. Err. & $\mathbf{t}$ & $\mathbf{P}>\mathbf{t}$ & \multicolumn{2}{|c|}{ [95\% Conf. Interval] } \\
\hline Enhance ICT in e-learning & 0.044626 & 0.006044 & 7.38 & 0.000 & 0.032763 & 0.056488 \\
\hline _cons & 0.39692 & 0.188449 & 2.11 & 0.035 & 0.027053 & 0.766787 \\
\hline
\end{tabular}

A linear regression was carried out to investigate whether teachers' perceptions on principals' enhancement of ICT in e-learning could significantly predict students' performance at KCSE. The results of the regression indicated that the model explained $13 \%$ of the variance and that the model was a significant predictor of exam performance, $\mathrm{F}(30,843)=4.13, \mathrm{p}=.001$. The realised coefficient was 0.04 therefore, for every unit increase in teachers' perceptions on principals' management of enhancement of ICT in elearning strategy; a 0.04 unit increase in KCSE mean score is predicted. The final predictive model was: KCSE score $=0.39+\left(0.044^{*}\right.$ enhancement of ICT $)$.

The findings reiterate those of Jehan and Feras (2018); Mohammad et al (2019); Muhammad, Irfanullah, Siraj, Hafiz and Rafid (2015); who all found significant relationship between use of ICT and students' academic performance and the learning process. Similarly, Ikwuka and Adigwe (2017), revealed that students who were taught with ICT had better academic performance. However, the findings disagree with Hussain et al (2017) results from the study on effects of ICT on students' academic achievement and retention in chemistry at secondary revealed that there was no significant variance in academic achievement of control and experimental groups on pretest. The findings further refute Mbaeze, Elochukwu and Choima (2010), findings that use of ICTs had no statistically significant relationship with students' academic performance. The findings disagree with Chiraz (2016), whose study on the impact of ICT on academic performance from higher education in Tunisia. He conducted a multilevel analysis to measure the impact of ICT access and use besides other student, university and teacher attributes that may affect academic performance and provided evidence for a distinctive though negative effect of ICT on performance which questions the effectiveness of educational policies in Tunisia. The findings however agree with Alandejani and Almadani (2018), who revealed that there exists a relationship between ICT adoption and academic performance in a conservative environment. The studies are also in agreement with Ikwuka and Eluemunor (2017), Mohammad et al (2019), Muhammad, Irfanullah, Siraj, Hafiz and Rafid (2015), who all revealed that students who were taught with ICT had better academic performance.

\section{Conclusion}

The study concluded that principals' enhancement of ICT in teaching and learning was perceived as a factor influencing students' academic performance. The study brings to light that information and communication technology positively affects students' 
academic achievement and retention and ICT was found more compelling, effective and valuable in teaching when contrasted with other techniques of teaching.

\section{Recommendations}

Schools should enhance change in ICT integration as it was noted to have a positive effect on the students' academic performance. Since ICT integration is a continuous process, school should endeavor to invest in ICT infrastructure development so that students' academic performance can be improved.

\section{Conflict of Interest Statement}

On behalf of all the co-authors I declare that authors have no conflict of interest with the manuscript.

\section{About the Authors}

Consolata Muthoni Kimuya is a PhD candidate in Educational Administration \& Management at Masaai Mara University. She has vast experience in high school teaching as well as institutional administration and management.

Dr. Gerald Kimani is a Lecturer in Curriculum Studies at the School of Education in the University of Nairobi. He has vast experience in university teaching, research, student supervision as well as institutional administration and management.

Dr. James Mwaura is a Lecturer in Psychology at the School of Education Maasai Mara University. He has vast experience in qualitative and quantitative research in educational statistics, measurement and evaluation. He has long university teaching experience and student supervision.

\section{References}

\section{a. Journal articles}

Alandejani, J. A., \& Almadani, F. M. (2018). ICT Adoption Impact on Students' Academic Performance: Evidence from Saudi Universities. Education Research International, 61-82.

Ali, F., Zhou, Y., Hussain, K., \& Nair, P. (2016). Does higher education service quality effect student satisfaction, image and loyalty? A study of international students. Quality Assurance in Education, 70-94.

Basri, W. S., \& Alandejani, J. A. (2018). ICT Adoption Impact on Students' Academic Performance: Evidence from Saudi Universities. Education Research International, 1-9.

Escalente, E. (2005). Organizational change; transformation strategies. Journal of Organization Change, 256-279. 
Ghavifekr, S., \& Wan Rosdy, W. (2015). Teaching and learning with technology: Effectiveness of ICT integration. International journal of research in education and science, $175-191$.

Guma Ali, F. A. (2013). The Role of ICT to Make Teaching-Learning Effective in Higher Institutions of Learning in Uganda. International Journal of Innovative Research in Science, Engineering and Technology Vol. 2, Issue 8, August 2013, 9-11.

Hussain, I., \& Suleman, Q. (2017). Effects of Information and Communication Technology (ICT) on Students' Academic Achievement and Retention in Chemistry at Secondary Level. Journal of Education and Educational Development, 73-93.

Jonassen, D. H. (2000). Transforming learning with technology: Beyond modernism and post-modernism. Educational technology, 21-25.

Kennah, R. (2016). The Use of ICT in the Teaching and Learning Process in Secondary Schools: A Case Study of Two Cameroonian schools. International Journal of Information Technology, 91-123.

Khan, M. S., Khan, I. U., Din, S. U., \& Muhammad, H. (2015). The impacts of ICT on the students' Performance: A Review of Access to Information. Journal on Humanities and Social Sciences, 256-352.

Laaria, M. (2013). Leadership challenges in the implementation of ICT in public secondary schools, Kenya. Journal of education and learning, 32-43.

Mbaeze, I., Ukwandu, E., \& Anudu, C. (2010). The Influence of Information and Communication Technologies on Students' Academic Performance. Journal of Information Technology Impact, 129-136.

Mbugua, N. S. (2016). Integration of information communication technology in teaching in public secondary schools in Nakuru County, Kenya. International journal of education and research, 271-282.

Mji, M. M. (2006). Factors associated with high school learners' poor performance: a spotlight on mathematics and physical science. Pretoria: South African journal of education.

Okiiya, W. et al. (2015). Change management and performance of public secondary schools in siaya sub county. International journal of scientific \& technology research , 172-173.

Rose, A., \& Kadveka, S. (2015). ICT (information and communication technologies) adoption model for educational institutions. Journal of Commerce and Management Thought, 558.

Sachs, J. D., Traub, G. S., Mazzucato, M., Messner, D., Nakicenovic, N., \& Rockström, J. (2019). Six transformations to achieve the sustainable development goals. Nature sustainability volume, 805-814.

Suhr, K. A., Hernandez, D. A., Grimes, D., \& Warschauer, M. (2010). Laptops and fourthgrade literacy: Assisting the jump over the fourth-grade slump. The journal of technology, learning and assessment, 61-76. 
Swanepoel, C. (2008). The perceptions of teachers and school principals of each other's disposition towards teacher involvement in school reform. South African journal of education, 39-51.

Victoria, O., \& Chikwature, W. (2016). Teachers' perception of the role of strategic planning in educational development at three mission secondary boarding schools in Manicaland Province. International journal of humanities social sciences and education, 57-66.

West, J. D., H. A., \& H. D. (2000). Learning through Leadership. Leadership for learning, 72-96.

\section{b. Theses}

Gikundi, Z. (2016). Factors influencing integration of information and communication technology in learning and teaching in public secondary schools: A Case of Tigania west sub county, Meru County, Kenya. Nairobi: University of Nairobi.

Imon, M. M. (2017). ICT integration in Secondary Education in Bangladesh: A study of Policy and Practice. Oslo: University of Oslo.

Oyeila, A. \&. (2016). Integrating information communication and technology in mathematics education at secondary level. Nairobi: Kenyatta University.

\section{c. Books}

Beare, C. B., \& M. R. (2005). Creating an excellent school: New management techniques. London: Routledge.

Berg, Taylor, Spaull \& Armstrong (2011). Improving education quality in south Africa. Stellenbosch: Department of economics, university of Stellenbosch.

Hrebiniak, L. G. (2013). Making strategy work: Leading effective execution and change. New Jersey: FT press.

Kaimenyi, J. T. (2015). Kenya vision 2030. Nairobi: Ministry of education science and technology.

Madsen, S. (2015). The "Hack" mindset for school-wide change. San Francisco: Getting smart.

MOE (2016). The national education sector plan (NESP). Nairobi: Ministry of Education.

Oztop, S. (2014). Public employees' perception towards management of organizational change. New York: McGraw Hill.

Society for International Development. (2010). Kenya's Vision 2030:An audit from an income and gender inequalities perspective. Nairobi: Society for International Development.

UNDP (2015). Quality education. New York City: United nation development program. UNESCO (2011). Transforming education: The power of ICT policies. Paris: UNESCO.

UNESCO (2018). Information and communication technology (ICT) in education. Paris: UNESCO. 
Vision 2030 delivery secretariat. (2015). Kenya Vision 2030. Nairobi: Vision 2030 delivery secretariat. makes clear that the materials are being reused under permission of a Creative Commons License. Views, opinions and conclusions expressed in this research article are views, opinions and conclusions of the author(s). Open Access Publishing Group and European Journal of Education Studies shall not be responsible or answerable for any loss, damage or liability caused in relation to/arising out of conflicts of interest, copyright violations and inappropriate or inaccurate use of any kind content related or integrated into the research work. All the published works are meeting the Open Access Publishing requirements and can be freely accessed, shared, modified, distributed and used in educational, commercial and non-commercial purposes under a Creative Commons Attribution 4.0 International License (CC BY 4.0). 